\title{
The Effectiveness of Red Grape (Vitis vinifera) Seed and Skin Extract Treatment on Staphylococcus aureus Bacteria that Causes of Urinary Tract Infections in Pregnant Women Examined by using White Mice (Mus musculus)
}

\author{
Satriya Manggala Liastra*, Ninuk Dwi Ariningtyas, Yelvi Levani \\ Department of Medicinal Education, Faculty of Medicine, Universitas Muhammadiyah Surabaya \\ Jl. Mulyorejo, Dukuh Sutorejo, Kec. Mulyorejo, Kota Surabaya, Jawa Timur 60115, Indonesia
}

\begin{abstract}
ARTICLE INFO
Article History:

Received: January, 2020

Revise: December, 2020

Accepted: January, 2021

Keywords: urinary tract infections; Vitis vinifera extract; natural antibiotic resveratrol, Mus musculus

Urinary tract infection or what is often called a UTI is an infectious disease of the urinary tract epithelium and is commonly caused by gram-positive bacteria, namely the Staphylococcus aureus, with a prevalence rate of 68 million patients in the world and 1.2 million patients in Indonesia. The diagnosis of UTI is established with a positive urine culture significance value $\geq 10^{5}(\mathrm{CFU}) / \mathrm{ml}$. The existing clinical management for cases of urinary tract infections in pregnant women uses amoxicillin to kill gram-positive bacteria, such as Staphylococcus aureus. However, there have been 469 cases of antibiotic resistance in pregnant women in Indonesia due to the non-compliance of using antibiotics for urinary tract infections. Vitis vinifera can be used as an alternative to natural bactericidal resveratrol containing anthocyanidin to kill gram-positive bacteria. This study used 28 white mice (Mus musculus) aged 6-21 weeks and weighing 120-200 grams injected with Staphylococcus aureus. The 28 subjects were divided into 4 groups, each of which consisted of 7 mice. The mice received K1 treatment with 250 $\mathrm{mg} / \mathrm{kgBW}$ of amoxicillin and treatments with 200,300 , and $500 \mathrm{mg} / \mathrm{KgBW}$ red grape seed and skin extract. Before treatments were given, a pre-test was conducted to ensure that the results were not biased. Post-test was also performed after the Staphylococcus aureus injection, which was measured after 5 days of urine culture that reached $10^{7}$ $\mathrm{CFU} / \mathrm{ml}$. The treatment in P3 using $500 \mathrm{mg} / \mathrm{KgBW}$ of red grape seed and skin extract contributed to the smallest result with $10^{2} \mathrm{Cfu} / \mathrm{ml}$, equals to the result produced by giving $250 \mathrm{ml} / \mathrm{KgBW}$ of amoxicillin.
\end{abstract}

\footnotetext{
*Corresponding author:

Satriya Manggala Liastra

Department of Medicinal Education, Faculty of Medicine, Universitas Muhammadiyah Surabaya

Email:anggaaajahhh123@gmail.com
} 


\section{INTRODUCTION}

Urinary tract infection is one of the major health problems in developing countries, including Indonesia (Kemenkes, 2014). The incidence of this disease in pregnant women in the world reached 68 million patients (WHO, 2015). According to the Indonesian Ministry of Health, a survey in 2013 recorded 1.2 million cases of urinary tract infections in pregnant women in Indonesia (Sujatmoko, 2015).

UTI is often characterized by clinical symptoms, such as pain when urinating, incomplete urination, and fever in UTI patients with a temperature that is not too high (Natharina, 2014). This is what commonly happens when the host's body defense decreases, especially in pregnant women (Shirby, 2013). The other risk factor is the shorter anatomical structure of the female urethra that contributes to a higher rate of UTI in women (Sylvia, 2015). In addition, multiple risk factor is more prevalent in pregnant women, which is a sudden change in vasopressin hormone that can increase the vulnerability of pregnant women to suffer from urinary tract infections (Soesanti, 2018).

Clinical management of urinary tract infection cases in pregnant women is carried out using amoxicillin for killing gram-positive bacteria such as Staphylococcus aureus. However, there have been recently a lot of cases of antibiotic resistance in pregnant women, reaching 469 cases, in Indonesia due to the non-compliance in the use of antibiotics for UTI (Fakhrizal, 2017).

Red grape is a fruit that is widely available around us. During the harvest season, particularly in the rainy season, this fruit is often consumed but the benefits from its seeds and skin have not been figured out. Literature studies have highlighted that red grapes' seeds and skin contain anthocyanidin substance (Sujatmoko, 2015). Moreover, research by Setiawan (2014) recorded that anthocyanidin can be used as natural resveratrol with its natural properties to reduce gram-positive bacteria activated with $95 \%$ ethanol compounds. After that, the researchers tried to develop and scrutinize the proper dosage of the substance as an alternative therapy for urinary tract infections.

\section{MATERIALS AND METHODS}

This study applied a true experimental method to experimental animals of white mice (Mus musculus) induced by Staphylococcus aureus bacteria, to investigate the proper dose and the results of Vitis vinifera extract administration to reduce the level of Staphylococcus aureus bacteria in the experimental animals. The extraction process applied the maceration method so that more anthocyanidin extract-rich yields could be obtained. This research was conducted using the randomized pre-test and post-test control group design method.

\section{Tools and Materials}

Tools

The tools used in this research were urine cups, disk plates, mortar, spoon, stoichiometric balance, scales, and personal protective equipment such as handscoons, masks, and lab coats.

\section{Materials}

The materials used to perform the experiments included standard feed for white mice, extraction of Vitis vinifera, $0.05 \mathrm{M}$ of citrate solution with $\mathrm{Ph}$ of $4.3-4.5,10 \%$ dextrose solution, $0.9 \% \mathrm{NaCl}$ solution, Staphylococcus aureus bacteria, ketamine for anesthesia in mice, and male mice (Mus musculus) aged around 6 weeks to 21 weeks, with a weight range of 120-200 grams.

\section{Research Design}

There have been many studies that proved the contents and benefits of Vitis vinifera for therapy in people with urinary tract infection. Therefore, the next step to carry out was a true experiment on white mice (Mus musculus), induced by UTI causing Staphylococcus aureus bacteria.

To determine the accurate dose and mechanism of Vitis vinifera to reduce the level of Staphylococcus aureus bacteria in experimental animals, randomized pre-test and post-test control 
group design was required and treatment was given to mice that had been induced with Staphylococcus aureus and made suffering from UTI, and then oral therapy with Vitis vinifera extract was given. After that, the level of Staphylococcus aureus was monitored using urine tests in the laboratory every day until the expected decrease in Staphylococcus aureus bacteria level was obtained and the mice were free from the bacterial colony.

\section{Research Population and Samples}

The population in this study were white mice (Mus musculus) raised in the Zoology Laboratory of the Department of Biology, Institut Teknologi Sepuluh November, Surabaya. The research team included inclusion criteria for samples, which among others were the experimental animals aged 6 weeks to 21 weeks and the animals had been certified healthy by the animal health center. A pre-test was carried out towards the experimental mice to ensure that the mice were healthy so that the results were not biased. The exclusion criteria were also considered, which were sick mice, infected mice, or dead mice.

\section{Research Procedures}

Replication was carried out in each group of at least 7 animals that would be multiplied by 4 treatment groups to obtain a minimum total sampling of 28 animals. This study applied a probability sampling technique with a type of stratified randomized sampling technique. This study was completed in three stages. First, a pretest was conducted by making the mice infected by

This study applied the cold maceration extraction method. The researchers used 95\% ethanol solvent, which is the optimal solvent in extraction because of its ability to produce a higher total yield, less amount of solvent remains, and shorter separation time if compared to distilled water. Ethanol is also more efficient and economical. The substance that was already extracted was rich in anthocyanidin, which has been
UTI through intravesical Staphylococcus aureus injection. Next, within 5 days, the mice were observed to figure out when the bacteria started to invade the epithelium of the urinary tract wall. Finally, after 5 days, the control group received 4 treatments in each test, including treatments with amoxicillin $250 \mathrm{mg} / \mathrm{KgBW}$, grape seed and skin extract at a dose of $200 \mathrm{mg} / \mathrm{KgBW}$, grape seed and skin extract at a dose of $300 \mathrm{mg} / \mathrm{KgBW}$, grape seed and skin extract at a dose of $500 \mathrm{mg} / \mathrm{KgBW}$. This research has been approved and legally certified by the Veterinary Ethics Committee section of the Faculty of Medicine, Universitas Muhammadiyah Surabaya with code of ethics letter number 002/KET/II.3.AU/ F/2020.

\section{Data Analysis}

To test the hypothesis, this study utilized a statistical analysis technique that examines and presents data using the Statistical Product and Service Solution (SPSS) program.

\section{Univariate Analysis}

The variables exploited in this study were the colony-forming unit and the dose of red grape seed and skin extract, which were analyzed statistically using frequency distribution tables and diagrams.

\section{Bivariate Analysis}

This study examined the relationship between the level of skin extract and red grapes extract and the level of Staphylococcus aureus in the urine of white mice (Mus musculus).

\section{RESULT AND DISCUSSION}

proven effective to reduce the level of Staphylococcus aureus bacteria.Since the maximum yield of anthocyanidin-rich extract reached $17.25 \%$, the researchers used the maceration method because of the faster process and a quite maximum level to be used as a research base (Table 1).

The bacterial colony levels were measured during the pre-test to determine and scrutinize 
whether the experimental mice were healthy or infected. If the result was already obtained and only normal floral bacteria were found, the research could be performed. After the intravesical injection of Staphylococcus aureus for 7 days, the results of the post-test were calculated and examined using the colony counting technique or the mayo technique with a specific method in the culture of Staphylococcus aureus bacteria. Finally, the level of the Staphylococcus aureus bacteria colony was obtained in $\mathrm{CFU} / \mathrm{ml}$ as presented in Table 2, Figure 1 and 2.

Before testing the differences in each treatment, a normality test was carried out to find out whether the normal assumptions were met and particular methods were appropriate. Since the research data were not normally distributed, the Shapiro-Wilk test was performed. The normality test resulted in the $p$-value of XXX in the four treatments and all types of tests, from the pre-test, injection of Staphylococcus aureus, and treatment with extract and control $\leq 0.05$. Moreover, it can be seen that H1 was accepted and the data were not normally distributed in all tests. After the normality test was carried out, the data homogeneity test was conducted to determine the distribution of data. The results of data analysis using the Lavene test are presented in Table 3.Table 3 demonstrates the results of the Lavene homogeneity test in pre-test and after Staphylococcus aureus intravesical injection, where data were homogenous because of $p$-value $\geq$ 0.05. Meanwhile, the data resulted from the tests on the experimental group after treatments and control group were not homogenous because of $a p$-value $\geq$ of 0.05 . The data were not normally distributed, and therefore, a nonparametric approach was applied using the Kruskal-Wallis test to obtain the significance values of differences in each test group as presented in Table 4.

Table 1. The comparison of the extraction results from experiments with maceration and percolation methods

\begin{tabular}{|c|c|c|c|c|c|c|}
\hline No. & Method & $\begin{array}{l}\text { Time } \\
\text { (hour) }\end{array}$ & $\begin{array}{c}\text { Before } \\
\text { Concentration }\end{array}$ & $\begin{array}{c}\text { After } \\
\text { Concentration }\end{array}$ & $\begin{array}{c}\text { Extract Weight } \\
\text { (gram) }\end{array}$ & $\begin{array}{c}\text { Extract } \\
\text { Yield (\%) }\end{array}$ \\
\hline 1. & $\begin{array}{l}\text { Cold } \\
\text { maceration }\end{array}$ & 20 hours & Dark red & $\begin{array}{l}\text { Thick liquid, } \\
\text { deep red }\end{array}$ & 17.68 & 17.25 \\
\hline 2. & Percolation & 22 hours & Dark red & $\begin{array}{l}\text { Watery liquid, } \\
\text { pink }\end{array}$ & 15.76 & 12.13 \\
\hline
\end{tabular}

Table 2. The mode as the reference for the level of Staphylococcus aureus bacteria colony

\begin{tabular}{lccc}
\hline Group & Pre-test & $\begin{array}{l}\text { Staphylococcus aureus } \\
\text { Injection }\end{array}$ & Post Treatment \\
\hline $\begin{array}{l}\mathrm{K} 1(\text { Amoxicillin with a dose of } 250 \\
\mathrm{mg} / \mathrm{kgBW})\end{array}$ & 3 & 7 & 2 \\
\hline $\begin{array}{l}\text { P1 (Extract of red grape seed and } \\
\text { skin with a dose of } 200 \mathrm{mg} / \mathrm{KgBW})\end{array}$ & 3 & 7 & 5 \\
\hline $\begin{array}{l}\text { P2 (Extract of red grape seed and } \\
\text { skin with a dose of 300mg/KgBW) }\end{array}$ & 3 & 7 & 4 \\
\hline $\begin{array}{l}\text { P3 (Extract of red grape seed and } \\
\text { skin with a dose of 500mg/KgBW) }\end{array}$ & 3 & 7 & 3 \\
\hline
\end{tabular}




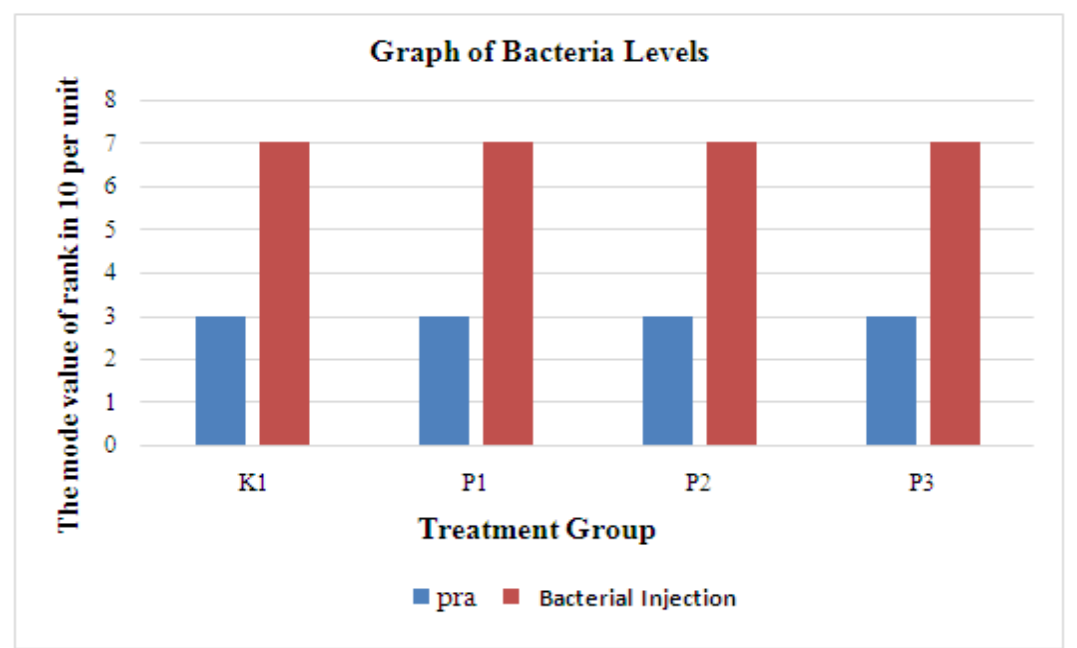

Figure 1. Graph of comparison of bacterial levels on pre-test and post-test after Staphylococcus aureus bacteria injection

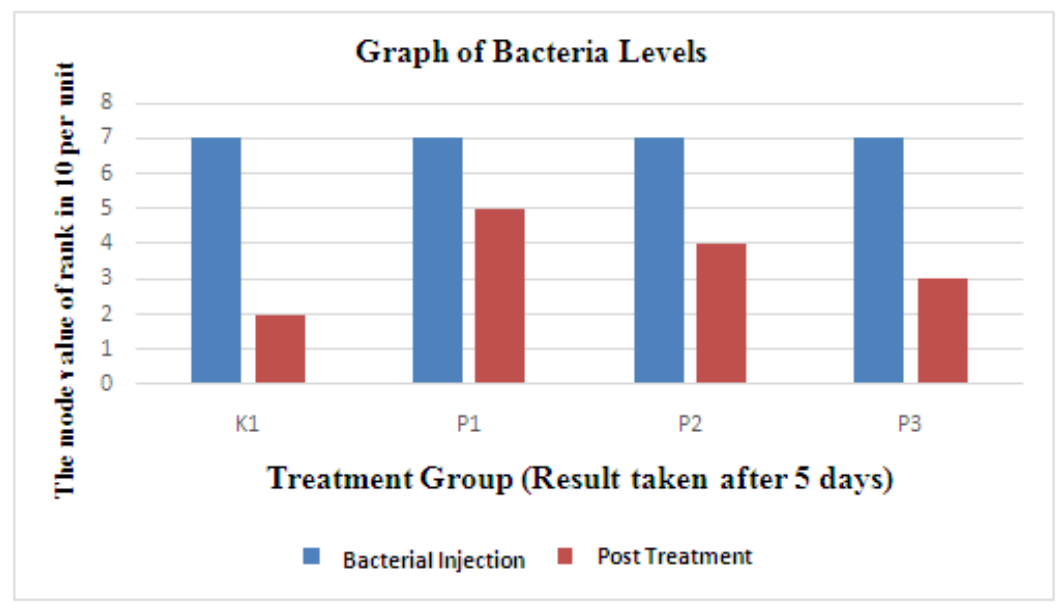

Figure 2. Graph of comparison of bacterial levels on post-test and after treatments $\mathrm{K} 1=$ Positive control group receiving treatment with $250 \mathrm{mg} / \mathrm{KgBW}$ of amoxicillin $\mathrm{P} 1=$ Treatment with $200 \mathrm{mg} / \mathrm{KgBW}$ of red grape seed and skin extract $\mathrm{P} 2=$ Treatment with $300 \mathrm{mg} / \mathrm{KgBW}$ of red grape seed and skin extract P3 $=$ Treatment with $500 \mathrm{mg} / \mathrm{KgBW}$ of red grape seed and skin extract

Table 3. The results of the pre-test, post-test, test for control group and tests after treatments

\begin{tabular}{ll}
\hline Type of Test & Sig.P-value \\
\hline Pre-test & 0.555 \\
\hline Staphylococcus aureus intravesical injection & 0.449 \\
\hline $\begin{array}{l}\text { Test on the control group and experimental group } \\
\text { receiving treatments with extracts }\end{array}$ & 0.000 \\
\hline
\end{tabular}

Table 4. The data resulted from the significance tests on the differences of groups with pre-test, post-test, test for the control group, and tests after treatments

\begin{tabular}{ll}
\hline Type of Test & Sig.P-value \\
\hline Pre-test & 0.872 \\
\hline Staphylococcus aureus intravesical injection & 0.908 \\
\hline $\begin{array}{l}\text { Test on the control group and experimental } \\
\text { group receiving treatments with extracts }\end{array}$ & 0.000 \\
\hline
\end{tabular}


Table 5 shows that the result of the pretest using the Kruskal-Wallis test did not show differences in the four treatments, with $a p$-value $\geq$ of 0.05 . It can be said that the condition of all mice was equal, with the normal bacterial flora in mice. The result of Staphylococcus aureus intravesical injection shows no difference in the four treatments, with $a p$-value $\geq 0.05$. The test on the control group and experimental groups receiving treatments with red grape seed and skin resulted in differences, with $a p$-value $\leq 0.05$, and therefore, a post-hoc test with Mann-Whitney test was required. Table 6 presents that the MannWhitney tests on five treatment combinations resulted in different levels of Staphylococcus aureus colonies with a $p$-value $\leq 0.05$, while the test on the combination of control with $250 \mathrm{mg}$ of amoxicillin and treatment with $500 \mathrm{mg}$ of red grape seed and skin extract produced with $p$-value $\geq 0.05$. To investigate the similarity of the decrease in Staphylococcus aureus levels in the combination of control with $250 \mathrm{mg}$ of amoxicillin and treatment with $500 \mathrm{mg}$ of red grape seed and skin extract, namely in the stages of Staphylococcus aureus injection, treatment with extract, and control, comparison test was carried out. The normality test yielded a result that the decrease was not normally distributed, with a $p$-value $\leq$ 0.05 , and thus, the Mann-Whitney test was required. The results of the MannWhitney test summarized in Table 6 signifies a no different decrease in Staphylococcus aureus levels in the control group and treatment group, indicated by $p$-value $\geq 0.05$. In other words, both groups demonstrate a relatively similar decrease in bacteria levels. Based on the obtained data, as illustrated in graphs and tables, the findings are significant and relevant to the objective of the present study.

Table 5. The results of tests on groups with combined treatments to figure out the significance values of differences

\begin{tabular}{lc}
\hline \multicolumn{1}{c}{ Treatment Combination } & Sig.P-value \\
\hline $\begin{array}{l}\text { Control with } 250 \mathrm{mg} \text { of amoxicillin and treatment with } 200 \mathrm{mg} \text { of red } \\
\text { grape seed and skin extract }\end{array}$ & 0.001 \\
\hline $\begin{array}{l}\text { Treatment with } 300 \mathrm{mg} \text { of red grape seed and skin extract and treatment } \\
\text { with } 500 \mathrm{mg} \text { of red grape seed and skin extract }\end{array}$ & 0.004 \\
\hline $\begin{array}{l}\text { Control with } 250 \mathrm{mg} \text { of amoxicillin and treatment with } 300 \mathrm{mg} \text { of red } \\
\text { grape seed and skin extract }\end{array}$ & 0.001 \\
\hline $\begin{array}{l}\text { Control with } 250 \mathrm{mg} \text { of amoxicillin and treatment with } 500 \mathrm{mg} \text { of red } \\
\text { grape seed and skin extract }\end{array}$ & 0.073 \\
\hline $\begin{array}{l}\text { Treatment with } 200 \mathrm{mg} \text { of red grape seed and skin extract and treatment } \\
\text { with } 300 \mathrm{mg} \text { of red grape seed and skin extract }\end{array}$ & 0.048 \\
\hline $\begin{array}{l}\text { Treatment with } 200 \mathrm{mg} \text { of red grape seed and skin extract and treatment } \\
\text { with } 500 \mathrm{mg} \text { of red grape seed and skin extract }\end{array}$ & 0.001 \\
\hline
\end{tabular}

Table 6. The data to investigate the decrease in the level of bacteria in the control with $250 \mathrm{mg}$ of amoxicillin and treatment with $500 \mathrm{mg}$ of red grape seed and skin extract

\begin{tabular}{llll}
\hline Group & \multicolumn{1}{l}{ Towards } & Sig.P-value \\
\hline K1 (Positive control with & 250 & P3 (500 mg of red grape seed and skin & 0.053 \\
$\mathrm{mg} / \mathrm{KgBW}$ of amoxicillin) & & extract) & \\
\hline
\end{tabular}

\section{CONCLUSION}

Based on the results of statistical tests and the study, it can be concluded that the outcomes of germ colony-level examination with mayo technique in mice with the treatment using red grape seed skin (Vitis vinifera) extract at a dose of 
$500 \mathrm{mg} / \mathrm{KgBW}$ appears to the most effective to reduce the level of Staphylococcus aureus bacteria. Both the positive control with the administration of $250 \mathrm{mg} / \mathrm{KgBW}$ of amoxicillin and treatment with $500 \mathrm{mg} / \mathrm{KgBW}$ of red grape seed and skin extract give equal effectiveness, as indicated by a decrease in the bacteria level by $102 \mathrm{CFU} / \mathrm{ml}$ with the Sig. $p$-value $<0.05$.

\section{REFERENCES}

Aini, N., Fatmaningrum, W., \& Yusuf, A. (2011). Upaya Meningkatkan Pasien dalam Tatalaksana ISK Dengan Pendekatan Teori Model Behavioral System Dorothy E. Johnson. Jurnal Ners, $\quad 6(1), \quad 1-10$ https://doi.org/10.4065/76.12.1204

Balouiri, M. (2016). Methods for In Vitro Evaluating Antimicrobial Activity: A Review. Journal of pharmacentical Analysis 6: Morocopp.71-79. https://doi.org/10.1016/j.jpha.2015.11.005

Dos Santos, K.C., (2017). Yacon (Smallanthus sonchifolius) Leaf Extract Attenuates Hyperglycemia and skeletal muscle Oxidative Stress and Inflammation in Diabetic Rats. Evidence-Based Medicine Complementary and Alternative $\quad$ Medicine, 2017. https://doi.org/10.1155/2017/64184048

Fakhrizal, E. (2017). Urinary Tract Infection in Woman Pregnancy. Jurnal pf Medical Faculty $\begin{array}{lll}\text { Riau University, } & \text { 8(2), }\end{array}$ https://doi.org/13.5475/56.14.1628
George, T. (2016). Clinical Pathophysiology of Urinary Tranct Infection in HIV Patients. Journal of Clinical Medical Practitioner, 9(5), 8-6. https://doi.org/12.9175/49.23.2416

Guyton A.C., \& Hall, J.E. (2008).Buku Ajar Fisiologi Kedokteran. Edisi 11. Jakarta : EGC

Irianto, K. (2011). Media Perkembangbiakan Bakteri Gram Positif dan Negatif. Jurnal Mikrobiologi, 7(4), 6-8 https://doi.org/18.6498/93.15.1864

Natharina, T. (2016). Manifestasi Klinis Infeksi Saluran Kemih Pada Ibu Hamil dan Pencegahannya. Jurnal Equivalent Universitas Indonesia, 3(1), 4-7 https://doi.org/11.7921/93.15.1659

Quesda, H. (2009). Ekstraksi Zat dalam Tanaman Herbal di Indonesia. Jurnal Ekstraksi Zat Tanaman Herbal, 4(5),2-4 https://doi.org/14.6311/85.16.3985

Setiawan, W. (2013).Buku Tanaman Obat Herbal di Indonesia: Bandung. 138-145.

Sherwood, L.(2014). Fisiologi Manusia: dari sel ke sistem. Edisi 8. Jakarta : EGC

Shirby, T. (2013). Pielonefritis in Pregnant Woman after 2 decades. Journal of London University, 6(1),9-11 https://doi.org/11.7311/24.30.2137

Soesanti, H. (2018). Ibu Hamil Rawan Mengalami Infeksi Saluran Kemih. Journal of Medical Inspiring, https://doi.org/14.9128/65.14.9148

Sujatmoko, W. (2015). Budidaya Tanaman Herbal di Indonesia. Jurnal Tanaman Bermanfaat, 4(8),8-10 https://doi.org/19.7123/95.30.1344

Suryanto, M. (2015). Penegakan Diagnosis pada ISK untuk Ibu Hamil. Jurnal Bakteriologi, 6(3),2-4 https://doi.org/24.5294/28.69.2286

Yirkov, S. (2016). Urinary Tract Infections In Modern Era of Pregnant Women. Journal of Medicines Moskow, 9(2),5-8 https://doi.org/20.9286/19.48.1397 